\title{
Working Variables Optimization of Resistance Spot Welding
}

Milan Brožek

Czech University of Life Sciences Prague, 16521 Prague 6 - Suchdol, Czech Republic, Phone: +420 224383265 , Email: brozek@tf.czu.cz

Resistance welding ranks among progressive and in practice often used manufacturing techniques of rigid joints. It is applied in single-part production, short-run production as well as in mass production. The basis of this method is in the utilization of the Joulean heat, which arises at the passage of current through connected sheets at collective influence of compressive force. The aim of the carried out tests was the optimization of the resistance spot welding working variables, concretely the determination of the dependence between the rupture force of spot welds made using sheets of different thickness and different welding conditions. For carrying out of this aim 650 assemblies were prepared. The test specimens of dimensions $100 \times 25 \mathrm{~mm}$ and thickness of $0.5 \mathrm{~mm}, 1.0 \mathrm{~mm}, 1.5 \mathrm{~mm}, 2.0 \mathrm{~mm}$, $2.5 \mathrm{~mm}$ and $3.0 \mathrm{~mm}$ were made from low carbon steel. In the place determined for welding the test specimens were corundum blasted and then degreased. The welding of two specimens always of the same thickness was carried out using the welding machine type BV 2,5.21. At this type the welding current value is constant $\left(I_{\max }=6.4 \mathrm{kA}\right)$. The welding time (the time of the passage of the current) was changed in the whole entirety, namely $0.10 \mathrm{~s}, 0.15 \mathrm{~s}$, $0.20 \mathrm{~s}, 0.25 \mathrm{~s}, 0.3 \mathrm{~s}, 0.4 \mathrm{~s}, 0.6 \mathrm{~s}, 0.8 \mathrm{~s}, 1.0 \mathrm{~s}, 1.3 \mathrm{~s}, 1.6 \mathrm{~s}$ and $2.0 \mathrm{~s}$. The compressive force was chosen according to the thickness of the connected sheets in the range from 0.5 to $2.4 \mathrm{kN}$. From the results of carried out tests it follows that using the working variables recommended by the producer we obtain the quality welds. But it we use the longer welding times, we can obtain stronger welds, namely of 5 to $35 \%$ compared to welds made using working variables recommended by the producer.

Keywords: Resistance welding; steel sheet; laboratory test; shear testing resistance spot welds

\section{Acknowledgement}

Supported by the Internal Grant Agency of the Czech University of Life Sciences Prague, Prague, Czech Republic project No. 2014:31140/1312/3133, titled “Influence of environmental conditions on constructional bonds".

\section{References}

[1] BLAŠČÍK, F. et al. (1987). Technológia tvárnenia, zlievárenstva a zvárania. [Technology of Forming, Founding and Welding]. ALFA, Bratislava.

[2] BROCKMANN, W. et al. (2009). Adhesive bonding: materials, applications and technology. Wiley-VCH, Weinheim.

[3] BROŽEK, M. (2014). Technical-economical evaluation of beech plywood bonding. In.: $13^{\text {th }}$ International Scientific Conference Engineering for Rural Development. pp. 168-173. Latvia University of Agriculture, Jelgava, Latvia.

[4] BROŽEK, M. (2013). Technical-economical evaluation of plywood bonding. In.: $5^{\text {th }}$ International Conference Trends in Agricultural Engineering. pp. 100-105. Czech University of Life Sciences Prague, Prague, Czech Republic.

[5] BROŽEK, M. (2013). Soldering steel sheets using soft solder. Research in Agriculture Engineering. Vol. 59, No. 4, pp. 141-146.

[6] BROŽEK, M. (2013). Soldering sheets using soft solders. Acta Universitatis Agriculturae et Silviculturae Mendelinae Brunensis. Vol. 61, No. 6, pp. 1597-1604.

[7] BROŽEK, M. (2013). Optimization of adhesive layer thickness at metal bonding using quick-setting adhesives. Manufacturing Technology. Vol. 13, No. 4, pp. 419-423.

[8] BROŽEK, M. (2012). Wear resistance of multi-layer overlays. In.: $11^{\text {th }}$ International Scientific Conference Engineering for Rural Development. pp. 210-215. Latvia University of Agriculture, Jelgava, Latvia.

[9] BROŽEK, M. (2011). Layer number influence on weld deposit chemical composition. In.: $10^{\text {th }}$ International Scientific Conference Engineering for Rural Development. pp. 393-397. Latvia University of Agriculture, Jelgava, Latvia. 
[10] BROŽEK, M., NOVÁKOVÁ, A. (1995). Porovnání jednostranných nýtů s trnem různých výrobců (Comparison of blind rivets of different producers). In.: XXXVI. konference kateder částí a mechanismů strojů (díl 1). pp. 3740. VUT Brno, Brno, Czech Republic.

[11] HAYAT, F., SEVIM, I. (2012). The effect of welding parameters on fracture toughness of resistance spotwelded galvanized DP600 automotive steel sheets. International Journal of Advanced Manufacturing Technology. Vol. 58, No. 9-12, pp. 1043-1050.

[12] HIPPERSON, J., WATSON, T. (1950). Resistance Welding.

[13] HIPPERSON, J. Recommended Machine Settings for Resistance Welding.

[14] HOLÁSEK, J. (1968). Odporové zváranie. [Resistance Welding]. Slovenské vydavatelství technické literatury, Bratislava.

[15] KAŠČÁK, L., SPIŠÁK, E. (2014). Effect of welding parameters on the quality of spot welds combining AHSS steel and HSLA steel. In.: $9^{\text {th }}$ International Conference on Local Mechanical Properties. pp. 162-165. Levoča, Slovak Republic.

[16] LI, R. X. (2012). Quality monitoring of resistance spot welding based on process parameters. In.: $2^{\text {nd }}$ International Conference on Advances in Energy Engineering. pp. 925-930. Bangkok, Thailand.

[17] LIU, H., WANG, H., ZHANG, X., LI, C. (2012). Optimization of parameters and research on joint microstructure of resistance spot welding of 201 stainless steel. In.: $2^{\text {nd }}$ International Conference on Advances in Materials and Manufacturing. pp. 1359-1363. Guilin, China.

[18] LIU, H., XU, X., ZHANG, X. (2013). Optimization of parameters and research on joint microstructure of resistance spot welding for 316 stainless steel. In.: $3^{\text {rd }}$ International Conference on Advances in Materials and Manufacturing Processes. pp. 2326-2329. Beihai, China.

[19] NIPPES, E.F. (1983). Metals Handbook. Vol. 6., Welding, Brazing, and Soldering. ASM International, Metal Park.

[20] PEASURA, P. (2011). The influence of welding parameters on effected the complete for resistance spot welding on mild steel. Advanced Materials Research. Volume 214, pp. 113-117.

[21] POURANVARI, M. (2011). Effect of resistance spot welding parameters on the HAZ softening of DP980 ferrite-martensite dual phase steel welds. World Applied Sciences Journal. Vol. 15, No. 10, pp. 1454-1458.

[22] RUŽA, V. (1988). Pájení. [Soldering.] SNTL, Praha.

[23] SVÍTIL, A. (1980). Odporové bodové svařování tenkých pozinkovaných ocelových plechů. Praha.

[24] TYLECOTE, R. F. (1941). The Spot Welding of Light Alloys.

[25] WANG, Z., WANG, Y., ZHANG, D. (2013). Optimization on parameters of resistance spot welding process for galvanized steel plate. Advanced Materials Research. Vol. 658, pp. 178-181.

[26] YOUNGER, A., GOURD, L. M., JUBB, J. E. M. (1966). An Investigation into the Fatigue Properties of a Single Spot Weld Lap Joint Cranfield. College of Aeronautics.

[27] ZHANG, H., SENKARA, J. (2012). Resistance Welding: Fundamentals and Applications. $2^{\text {nd }}$ ed., CRC Press, Boca Raton.

[28] Tentative Standards and Recommended Practices and Procedures for Spot Welding of Aluminium Alloys (1942). American Welding Society, New York.

[29] ČSN EN ISO 4063. Svařování a příbuzné procesy - Přehled metod a jejich číslování (Welding and allied processes - Nomenclature of processes and reference numbers).

[30] ČSN EN ISO 14273. Rozměry vzorku a postup zkoušení střihem odporových bodových, švových a výstupkových svarů (Specimen dimensions and procedure for shear testing resistance spot, seam and embossed projection welds).

[31] ČSN EN 1465. Lepidla - Stanovení pevnosti ve smyku při tahovém namáhání přeplátovaných lepených soustav (Adhesives - Determination of tensile lap-shear strength of bonded assemblies). 